University of Nebraska - Lincoln

DigitalCommons@University of Nebraska - Lincoln

2019

\title{
Crustal structure of Mesozoic rifting in the northeastern Gulf of Mexico from integration of seismic and potential fields data
}

Mei Liu

Irina Filina

Paul Mann

Follow this and additional works at: https://digitalcommons.unl.edu/geosciencefacpub

Part of the Earth Sciences Commons

This Article is brought to you for free and open access by the Earth and Atmospheric Sciences, Department of at DigitalCommons@University of Nebraska - Lincoln. It has been accepted for inclusion in Papers in the Earth and Atmospheric Sciences by an authorized administrator of DigitalCommons@University of Nebraska - Lincoln. 


\title{
Crustal structure of Mesozoic rifting in the northeastern Gulf of Mexico from integration of seismic and potential fields data
}

\author{
Mei Liu, ${ }^{1}$ Irina Filina, ${ }^{2}$ and Paul Mann ${ }^{1}$ \\ 1 University of Houston, Department of Earth and Atmospheric Sciences, \\ Houston, Texas, USA. E-mail: mliu30@uh.edu; pmann@uh.edu. \\ 2 University of Nebraska-Lincoln, Department of Earth and Atmospheric \\ Sciences, Lincoln, Nebraska, USA. E-mail: ifilina2@unl.edu.
}

\begin{abstract}
We have investigated the crustal structure of a $400 \mathrm{~km}$ wide zone of thinned continental crust in the northeastern Gulf of Mexico (GOM) using gravity and magnetic modeling along two deeply penetrated seismic transects. Using this approach, we identify two zones of prominent, southward-dipping reflectors associated with 7-10 km thick, dense, and highly magnetic material. Previous workers have interpreted the zones as either coarse clastic redbeds of Mesozoic age that are tilted within half-grabens or seaward-dipping reflectors of magmatic origin. Both seismic reflection lines reveal a 10 $\mathrm{km}$ thick and $67 \mathrm{~km}$ wide northern zone of high density near the Florida coastline beneath the Apalachicola rift (AR). The southern zone of high density occurs $70 \mathrm{~km}$ to the south in the deepwater central GOM along the northern flank of the marginal rift, a $48 \mathrm{~km}$ wide, southeast-trending structure of inferred Late Jurassic age that is filled
\end{abstract}

Published in Interpretation, Vol. 7, No. 4 (November 2019); p. T857-T867.

doi:10.1190/INT-2018-0259.1

Copyright (C 2019 Society of Exploration Geophysicists and American Association of

Petroleum Geologists. Used by permission

Submitted 22 December 2018; revised 15 June 2019; published 16 July 2019. 
by $3 \mathrm{~km}$ of low-density and low-magnetic susceptibility sediments including complexly deformed salt deposits. We propose that these two subparallel rifts and their associated magmatic belts formed in the following sequence: (1) AR formed during Triassic-early Jurassic (210-163 Ma) phase 1 of diffuse continental stretching and was partially infilled on its northern edge by southward- dipping volcanic flows; and (2) the similarly southward-dipping southern magmatic zone formed adjacent to the marginal rift during the early phase 2 of late Jurassic (161-153 Ma) rifting of the GOM continental extension; this southern area of SDR formation immediately preceded the formation of the adjacent oceanic crust that separated the rift-related evaporates into the northern and southern GOM. Our integrated approach combining 2D seismic, gravity, and magnetic data sets results in a more confident delineation of these deep crustal features than from seismic data alone.

\section{Introduction}

Since the publication of high-resolution satellite gravity images of the Gulf of Mexico (GOM) basin by Sandwell et al. (2014), most workers now accept that the GOM opened during two distinct rift phases that spanned the period from the late Triassic to the earliest Cretaceous (Hudec et al., 2013; Eddy et al., 2014; Nguyen and Mann, 2016). The late Triassic-middle Jurassic (210-163 Ma) phase 1 presalt rifting was recorded by a broad zone of northeast-trending rifts in the northeastern GOM that reflected northwest to southeast continental extension between the North and South American continents and the intervening continental Yucatan block (Figure 1) (Buffler and Sawyer, 1985; Hudec et al., 2013; Snedden et al., 2014; Steier and Mann, 2019). The aftermath of phase 1 rifting included the formation of a large unfaulted sag basin into which the Louann-Campeche salt of Callovian age (163-161 Ma) was deposited (Hudec et al., 2013; Snedden et al., 2014). Callovian salt generally thickens into sag basins either as a result of increasing accommodation and enhanced deposition related to thermal subsidence of the underlying rift or as the result of the downslope movement along mobile salt rollers (Steier and Mann, 2019). This extensive salt basin formed a broad (approximately 200-688 km) and thick $(6 \mathrm{~km})$ sag basin in the western GOM, but it thinned to zero along a narrow (approximately 68 $\mathrm{km}$ wide) eastward-trending seam in the eastern GOM (Steier and Mann, 2019) (Figure 1). This eastward-thinning pattern of the extensive evaporite deposit has led previous workers to propose that oceanic spreading propagated across the incipient central GOM from west to east (Marton 


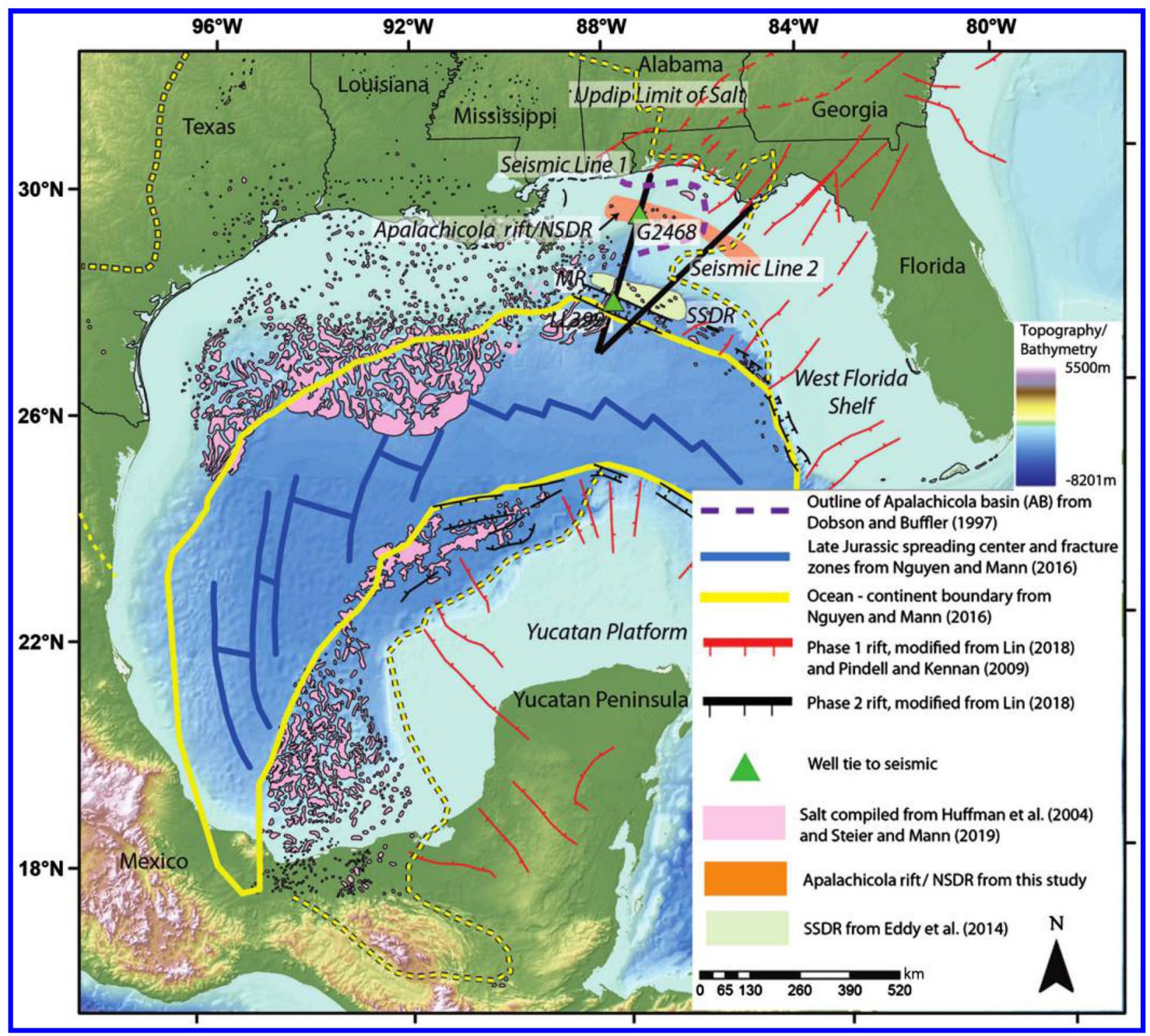

Figure 1. Tectonic map of the eastern GOM showing the location of our two megaregional seismic lines relative to the locations of (1) Late Triassic-Early Jurassic Phase 1 rifts, (2) Callovian salt deposits (Steier and Mann, 2019), (3) Late Jurassic Phase 2 rifts, and (4) Late Jurassic-earliest Cretaceous spreading ridges and its flanking area of oceanic crust in the deep central GOM (Lin, 2018) in the northeastern GOM. The lightgreen polygon shows the SSDR province mapped by Eddy et al. (2014). The dashed purple line shows the outline of the Apalachicola Basin (AB) from the mapping of a seismic reflection grid by Dobson and Buffler (1997). Salt diapirs from Huffman et al. (2004) and Steier and Mann (2019) are shown as pink polygons. The yellow dotted line shows the updip limit of Louann salt compiled from Rowan (2014) and Steier and Mann (2019). 
and Buffler, 1994) and that influx of the Pacific Ocean into the western GOM provided the source of thicker and more extensive salt deposits in that area (Steier and Mann, 2019).

The Late Jurassic (161-153 Ma) rift phase 2 was recorded by more localized and crosscutting "marginal rifts" or "outer troughs" that immediately preceded the formation of the adjacent Late Jurassic-earliest Cretaceous (154-137 Ma) oceanic crust in the central deepwater GOM (Hudec et al., 2013; Snedden et al., 2014; Lin et al., 2019) (Figure 1). These phase 2 marginal rifts are immediately adjacent to and subparallel with the ocean-continent boundary (OCB) along the Yucatan- Florida conjugate margins (Escalona and Yang, 2013; Lin et al., 2019; Steier and Mann, 2019) as well as along the northwestern GOM-Campeche conjugate margins (Hudec and Norton, 2019). This crescent-shaped area of central GOM oceanic crust with its complex pattern of short spreading ridges offset by fracture zones (Figure 1) had been previously mapped from regional seismic refraction surveys, potential field studies, and deeply penetrating seismic profiles (Buffler and Sawyer, 1985; Marton and Buffler, 1999; Bird et al., 2005; Pindell and Kennan, 2009; Pindell et al., 2016).

The formation of the Late Jurassic-earliest Cretaceous oceanic crust split the single preoceanic salt basin into two widely separated salt areas: the Louann salt in the U.S. GOM and the Campeche salt in the Mexican GOM (Pindell and Kennan, 2009; Hudec et al., 2013; Pindell et al., 2016; Steier and Mann, 2019) (Figure 1). Snedden et al. (2014) and Lin et al. (2019) document Late Jurassic-recent sedimentary infilling of the area of oceanic crust and use the age of downlap to infer the timing of the formation of oceanic crust to be between 154 and $137 \mathrm{Ma}$ along a slow (2.2-2.4 cm/year)-spreading ridge (Figure 1) (Hudec et al., 2013; Snedden et al., 2014).

One area of continuing controversy for the GOM opening history that also forms the main objective of this paper is evidence for phase 1 rifting and associated magmatic activity beneath the thickly sedimented northeastern GOM (Figure 1). Because phase 1 structures in this area are older, more deeply buried to depths approximately $10 \mathrm{~km}$, and locally mantled by a $2-5 \mathrm{~km}$ thick salt layer, seismic reflection data are more challenging to interpret and need careful integration with gravity and magnetic observations and models. Previous workers such as MacRae and Watkins (1995) and Dobson and Buffler (1997) use industry seismic grids to propose that thick, layered units seen on seismic 
lines in the northeastern GOM are the coarse conglomerate and sandstone that are equivalent to the coarse-grained clastic rocks of the Eagle Mills Formation described from the subsurface of the northern GOM (Warwick, 2017). These workers also propose that these units were uniformly tilted southward in the direction of oceanic crust in the central GOM because of their Mesozoic deposition and rotation within Phase 1 half-grabens. In contrast, other workers - including Imbert (2005), Imbert and Philippe (2005), Eddy et al. (2014), Van Avendonk et al. (2015), Pascoe et al. (2016), and Curry et al. (2018) - proposed that these reflectors represented "seaward-dipping reflectors (SDRs)" or layered volcanic flows that accompanied the phase 1 rifting event as part of a volcanic margin setting prior to Late Jurassic salt deposition (163-161 Ma).

Eddy et al. (2014) use 2D industry seismic lines to identify two zones of SDRs: (1) a southern SDR zone (SSDR) adjacent to the OCB that was previously described by MacRae and Watkins (1995) and Dobson and Buffler (1997) and (2) a northern SDR zone (NSDR) within the Apalachicola rift (AR) approximately $180 \mathrm{~km}$ north of the oceanic OCB (Figure 1). Eddy et al. (2014) suggest that the northern zone may be part of an "inner wedge" system of synrift basins that were filled with basalts and volcaniclastic sediments during continental extension and that the southern zone was an "outer wedge" overlying more thinned and distal continental crust as described by Planke et al. (2000) from other rifted continental margins.

Our study combines the following geophysical and geologic data sets to better understand the rifted crustal structure in this area: (1) two regional seismic profiles (lines DeepEast 533 and DeepEast 1547) ranging in length up to approximately $370 \mathrm{~km}$, which were kindly provided to us by Spectrum Geo (Figure 1), (2) published satellite gravity data (Sandwell et al., 2014), (3) published magnetic data (Bankey et al., 2002; Meyer et al., 2017), and (4) public well data (Gulf Oil Corporation, 1975; Buffler et al., 1984; Hilterman, 1998). We use all of these data sets to constrain two integrated geophysical models that improve the locations of the OCB, the AR and marginal rift, and the proposed NSDR and SSDR magmatic zones. We also performed a spatial analysis of gravity and magnetic fields to improve our interpretation of tectonic structures. 


\section{Data and methods}

\section{Seismic data}

In 2010, investigators of the GOM Basin Opening Project (GUMBO) used seismic refraction transects to study the lithologic composition and structural evolution of the GOM (Duncan, 2013; Christeson et al., 2014; Eddy et al., 2014). Ocean-bottom seismometers (OBS) and an air-gun seismic source were used to collect seismic refraction data along four dip profiles of the U.S. northern GOM. The OBS spacing for transects in the northeastern GOM is $12 \mathrm{~km}$ with a time sampling interval of $5 \mathrm{~ms}$ and a shot spacing of $150 \mathrm{~m}$ (Duncan, 2013).

GUMBO3 (model 1 in Figures 1 and 2a) extends from offshore Florida, across De Soto Canyon, to the deep central GOM. Figure 2a shows the interpretation of three major subsurface layers from seismic refraction data based on velocity structure. Eddy et al. (2014) interpret the OCB to be located at $290 \mathrm{~km}$ along the profile. We used the first $330 \mathrm{~km}$ of this profile to study the architecture of the rifted continental margin. Two zones of faster seismic velocity were imaged within the lower crustal layer and can be interpreted as underplating in the lower crust. These faster velocity zones correlate with high-amplitude anomalies in the observed magnetic field as noted by Eddy et al. (2014).

We used two seismic profiles from Spectrum Geo DeepEast data set to interpret crustal features and constrain 2D crustal models using potential fields data. The DeepEast survey was acquired in 2007 with an average line spacing of approximately $50 \mathrm{~km}$, a shotpoint interval of $37.5 \mathrm{~m}$, and a two-way time record length of $14 \mathrm{~s}$. The seismic data were depth migrated.

Figure $2 \mathrm{~b}$ shows the first $330 \mathrm{~km}$ of seismic reflection profile DeepEast 533 that is coincident with the GUMBO3 transect. We built geophysical model 1 along this seismic reflection profile to better constrain the sedimentary section and the upper crust. GUMBO3 was used to constrain the crustal thickness and the intrusions within the lower crust (Figure 2a). Figure 2c shows part of 2D seismic reflection line DeepEast 1547 that was used to constrain the sedimentary section and upper crust of geophysical model 2 . 


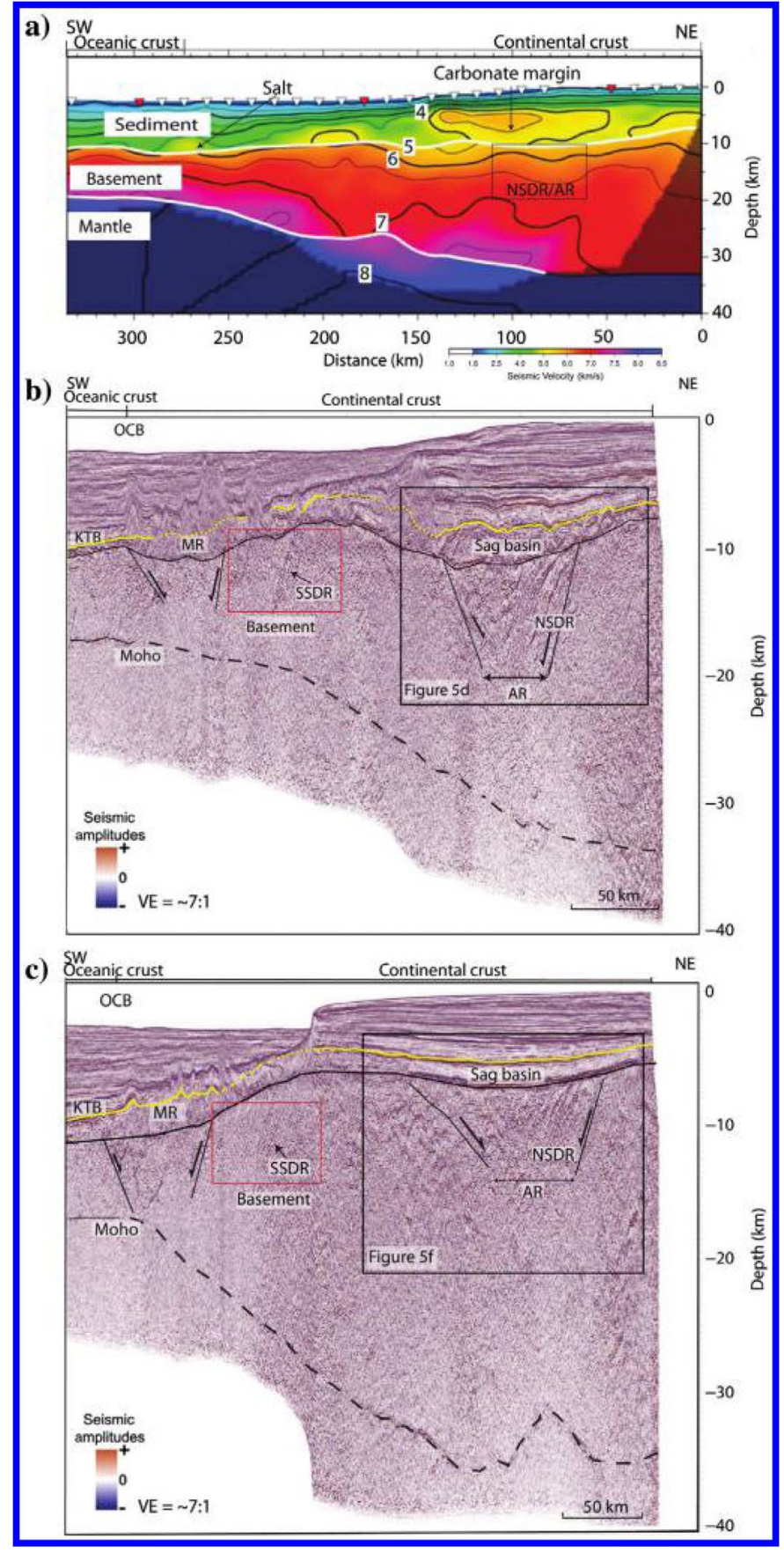

Figure 2. (a) Cross section modified from seismic refraction experiment along GUMBO3 (Eddy et al., 2014). This GUMBO profile was used to constrain the crustal layers of the integrated geophysical model 1 that is shown in Figure 3a. NSDR, northern SDR; AR, Apalachicola rift. (b) Seismic reflection profile 1 is from the Spectrum DeepEast 533 seismic reflection line and was used to constrain the sedimentary layers and the basement of model 1 as shown in Figure 3a. (c) Seismic reflection profile 2 is from the Spectrum DeepEast 1547 seismic reflection line and was used to build model 2 as shown in Figure $3 \mathrm{~b}$. The boxed areas on seismic lines shown in ( $b$ and $c$ ) are magnifications of both lines in Figure $5 \mathrm{~d}$ and $5 \mathrm{f}$, respectively, in the area of the AR basin. See the text for details. 


\section{Methodology}

Integrated geologic and geophysical analysis

Free-air satellite gravity field data (Sandwell et al., 2014) and the United States Geological Survey (USGS) regional magnetic compilation (Bankey et al., 2002) were used in developing integrated geophysical models and for mapping the major tectonic structures such as the $\mathrm{OCB}$, northern and southern SDR provinces, and the marginal rift basin that flanks the area of the Late Jurassic oceanic crust underlying the deepwater GOM. The reported accuracy of the free-air gravity data set is approximately $2 \mathrm{mGal}$ (Sandwell et al., 2014). Before sampling and modeling, the magnetic data set was reduced to the pole (RTP) to remove the skewness of magnetic anomalies due to nonverticality of the ambient magnetic field. Because most of the USGS magnetic data were collected in 1985 in the northeastern GOM, the following parameters from the magnetic epoch for 1985 were used during the reduction to the pole transformation: inclination of $55.77^{\circ}$, declination of $4.21^{\circ}$, and total intensity of $48,785 \mathrm{nT}$.

We divided the subsurface of the GOM into several layers and assigned physical properties (density and magnetic susceptibility) to each layer based on well data (sedimentary layers and the upper continental crust) or published values for various types of rocks (lower continental and oceanic crustal units). Exploration well G2468 (BOEM) located $8 \mathrm{~km}$ west of line DeepEast 553 (Figure 1) was used to constrain the top of the carbonate platform (91.44 m or $300 \mathrm{ft})$. With limited basement- penetrated wells in the GOM, we used well 538A from the Deep Sea Drilling Project (DSDP) (Buffler et al., 1984) in the southeastern GOM to constrain the bulk density of the upper continental crust. The general density-velocity trend from 447 deepwater wells (Hilterman, 1998) was modified from Filina et al. (2015). The response of potential fields was computed for each model and compared with the observed signal. The model was then adjusted to ensure a good match between observed and calculated signals in gravity and magnetic data, and it was checked for consistency with seismic, gravity, magnetic, and well-log information. All gravity and magnetic modeling were performed using Geosoft's Oasis Montaj software.

\section{Spatial analysis}

Major geologic boundaries are expressed by different polarities, amplitudes, and wavelengths of the potential fields data and depend on 
the magnitude of the contrasts in physical properties, geometry, and the depth of the contact between juxtaposed rocks. Hence, the recorded potential fields represent the combination of all the signals related to various geologic structures in the subsurface. To highlight the specific crustal structures, we first need to remove the unnecessary signals.

We performed Bouguer correction on the free-air gravity field by taking into account the gravity effect of water (density of $1030 \mathrm{~kg} / \mathrm{m}^{3}$ ) over the unconsolidated sediments with an assumed density of $2000 \mathrm{~kg} / \mathrm{m}^{3}$. We also removed the regional trend due to gravity effects of deep structures, including the Moho boundary, by an upward continuation to an elevation of $40 \mathrm{~km}$.

Despite its finer sampling interval of $1 \mathrm{~km}$, the USGS magnetic data set does not cover the region of offshore Florida. Instead, we made the spatial analysis using the EMAG_V3 data set (Meyer et al., 2017) from the National Oceanic and Atmospheric Administration (NOAA) with a spatial resolution of 2 arc minutes (approximately $3.6 \mathrm{~km}$ in the GOM). Some grids and track line data collected during the period of 1946-2014 are included in EMAG2_V3. Lacking detailed information about when the magnetic data in northeastern GOM were collected, we used the same parameters as the USGS magnetic data set from the epoch for 1985 to reduce EMAG2_V3 to the pole.

A series of derivative filters (mathematical transformations) was applied to highlight lineaments in both gravity and magnetic data sets. The correlation of the observed lineaments with the geologic structures determined from the two modeled profiles was used to extend the interpretation to the area outside of seismic coverage. Information from the analysis of the gravity and magnetic data was used to map the extent of the marginal rift basin, the northern and southern provinces, and the OCB.

\section{Results}

\section{Model 1}

Model 1 (Figure 3a) comprises 17 layers each with its own density and magnetic susceptibility. The upper $10 \mathrm{~km}$ consists of eight sedimentary layers with their modeled densities that include Pleistocene $\left(2250 \mathrm{~kg}^{3}\right)$, Pliocene $\left(2350 \mathrm{~kg} / \mathrm{m}^{3}\right)$, Miocene $\left(2400 \mathrm{~kg} / \mathrm{m}^{3}\right)$, Paleogene $\left(2450 \mathrm{~kg} / \mathrm{m}^{3}\right)$, 


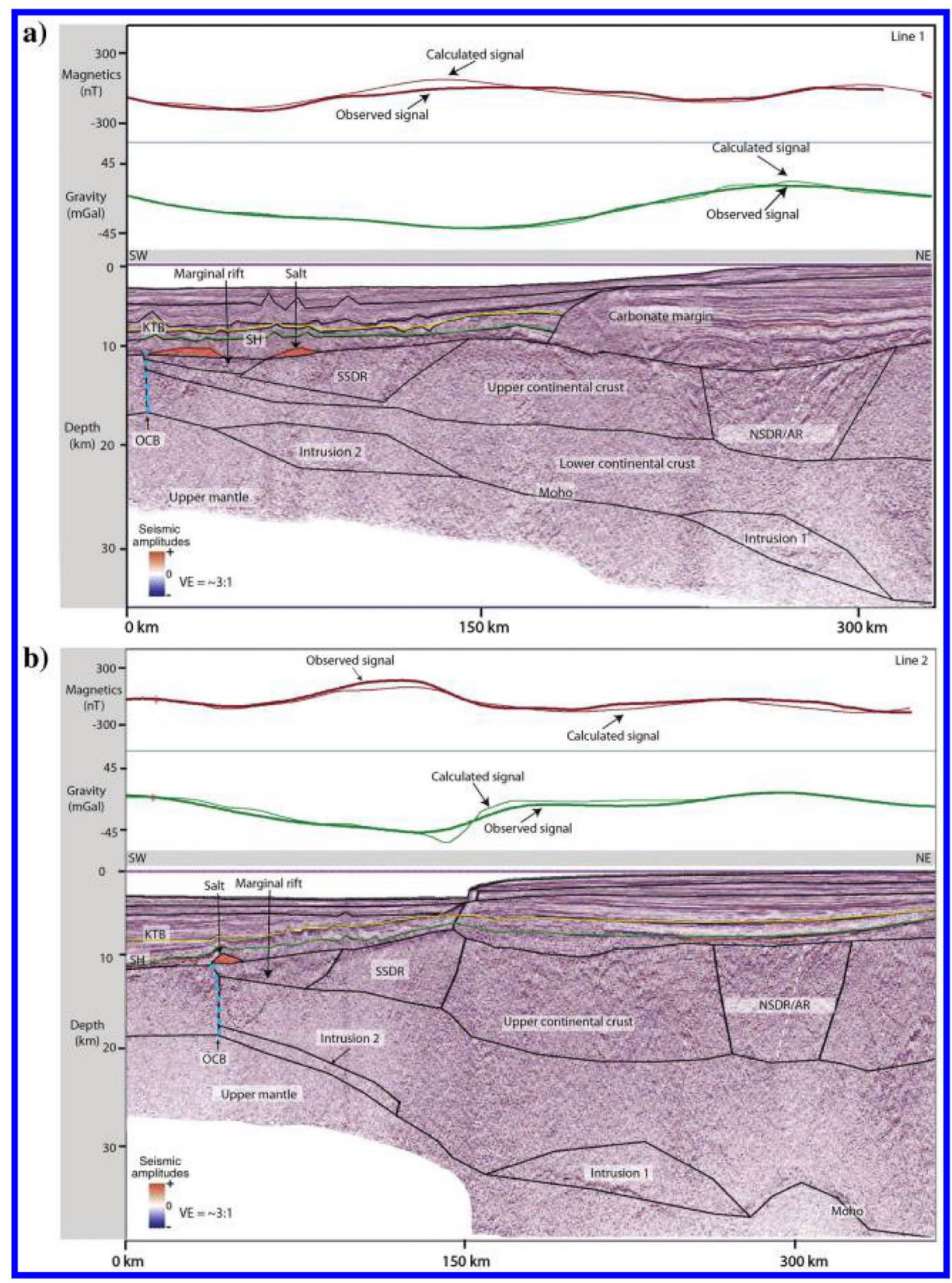

Figure 3. (a) Integrated geophysical model 1 that is coincident with the GUMBO3 refraction line (Figure 2a) and the Spectrum DeepEast 533 reflection line (Figure 2b). The black lines outline the subsurface layers. The SSDR province is adjacent to the marginal rift basin that filled with the sediments, reactivated salt, whereas the NSDR province is contained within the AR. The dashed white line shows the proposed boundary between sedimentary-filled AR to the southwest and the NSDR to the northeast. The interpreted OCB is shown as a blue dotted line. (b) Integrated geophysical model 2 that is constrained by the Spectrum DeepEast 1547 seismic reflection profile. The black lines in the bottom panel outline subsurface layers. The NSDR/AR province is located above an elevated Moho, whereas the SSDR province occurs adjacent to the marginal rift basin. The OCB is shown as a blue dotted line. 
Mesozoic $\left(2550 \mathrm{~kg} / \mathrm{m}^{3}\right)$, salt $\left(2150 \mathrm{~kg} / \mathrm{m}^{3}\right)$, carbonate rocks $\left(2600 \mathrm{~kg} / \mathrm{m}^{3}\right)$, and marginal rift sedimentary rocks $\left(2550 \mathrm{~kg} / \mathrm{m}^{3}\right)$. The magnetic susceptibility of the sedimentary section was assumed to be zero except for the marginal rift sediments (400 microcentimeter-gram-second [ $\mu \mathrm{cgs}]$ ), which was proposed by MacRae and Watkins (1995) to consist of redbeds. The southern SDR (SSDR in Figure 3a) province was assigned a density of $2850 \mathrm{~kg} / \mathrm{m}^{3}$ and a magnetic susceptibility of $4000 \mu \mathrm{cgs}$. The northern province (NSDR/AR in Figure 3a) was assigned the same physical properties as the SSDR.

The crust along model 1 changes from a relatively unstretched continental crust at the northeastern end of the line to a much thinner oceanic crust that underlies the central deepwater GOM at the southwestern end of the line (Figure 3a). The bottom layer of the model is mantle with a density of $3300 \mathrm{~kg} / \mathrm{m}^{3}$ and magnetic susceptibility of $0 \mu \mathrm{cgs}$. The overall physical properties of the modeled rocks are consistent with similar studies performed by Filina (2018), 2019), and Filina and Hartford $(2018,2019)$ in the southern GOM. The only difference between model 1 and the lines modeled by Filina $(2018,2019)$ is the increased magnetic susceptibilities of the crustal rocks in the northeastern GOM with respect to the northwestern and central GOM. This magnetic variation at the scale of the entire GOM is consistent with the west-to-east increase in magmatism in the GOM (Eddy et al., 2018).

In the northern continental area of model 1 , the crust is composed of two layers - the upper and the lower continental crust. The thickness of the upper continental crust varies between 6 and $13 \mathrm{~km}$. This layer has a density of $2780 \mathrm{~kg} / \mathrm{m}^{3}$ as constrained by DSDP well 538A (Buffler et al., 1984), and it has a magnetic susceptibility of $3500 \mu \mathrm{cgs}$. The NSDR region is constrained within the AR as previously interpreted by Dobson and Buffler (1997) and shown on the Spectrum seismic reflection line in Figure 3 . The NSDR is $67 \mathrm{~km}$ wide and up to $10 \mathrm{~km}$ thick (at the model distance of 22-89 km; Figures 2b, 3, and 4).

From seismic reflection data alone, it is difficult to distinguish magmatic layering of the NSDR from sedimentary layering of the rift fill. Using seismic reflection data alone, MacRae and Watkins (1995) interpreted that most of the rift fill was a sedimentary wedge in a halfgraben setting. Based on our potential fields modeling, we interpret a magmatic SDR origin for the strongly layered, higher density, and higher magnetic susceptibility packet of seismic reflectors within the northern part of the AR (Figure 3). Our interpretation of a magmatic NSDR is consistent with 
previous interpretations by Imbert (2005), Imbert and Philippe (2005), Eddy et al. (2014), Van Avendonk et al. (2015), Pascoe et al. (2016), and Curry et al. (2018).

For the SSDR and the AR in the north, the strongest and most planar reflectors, that are inferred to be volcanic flows dip southward toward the oceanic crust of the deepwater GOM and are located within or along the northern flanks of the rifts (Figure $3 a$ ). To satisfy gravity and magnetic signals, both regions must be filled with rocks of the higher density of $2850 \mathrm{~kg} \mathrm{~m}^{3}$ and magnetic susceptibility of $4000 \mu \mathrm{cgs}$ that is higher than the upper crust. The SSDR province has a lateral extent of $40 \mathrm{~km}$ in Figure 3a, and it is $12 \mathrm{~km}$ wider than the SSDR province interpreted by Eddy et al. (2014) on GUMBO3. According to model 1, this inferred SSDR province is $10 \mathrm{~km}$ thick (Figure $3 \mathrm{a}$ ). The marginal rift in the south is $3 \mathrm{~km}$ thick, $48 \mathrm{~km}$ wide, and bounded by the SSDR in the north and the OCB in the south. The density of the marginal rift section is assumed to be $2600 \mathrm{~kg} / \mathrm{m}^{3}$, and the magnetic susceptibility is assigned as $400 \mu \mathrm{cgs}$.

The lower continental crust was assumed to have a density of 2920 $\mathrm{kg} / \mathrm{m}^{3}$ (Carlson and Herrick, 1990) with a magnetic susceptibility of 5500 $\mu \mathrm{cgs}$. These parameters were determined during the modeling based on an improved fit between the observed and computed magnetic fields. The derived magnetic susceptibility is generally consistent with the range of 2000-6900 $\mu$ cgs for the rocks of the lower continental crust as proposed by Schnetzler (1985). The ocean crust was assigned a density of 2850 $\mathrm{kg} / \mathrm{m}^{3}$ and magnetic susceptibility of $6000 \mu \mathrm{cgs}$ for models 1 and 2 .

We interpreted the OCB to be located at a distance of $301 \mathrm{~km}$ along model 1, which is coincident with a prominent magnetic trough (Figure $3 a$ ). The magnetic signal is very sensitive to the location of the OCB in this model. The model also suggests the presence of two anomalous, high-density bodies (intrusions 1 and 2) within the lower continental crust that are located between 46-119 and 196-280 km along the length of model 1. We modeled these intrusive bodies with a density of 2950 $\mathrm{kg} / \mathrm{m}^{3}$ and magnetic susceptibility of $-8000 \mu \mathrm{cgs}$.

The presence of intrusive bodies was constrained by their distinctive magnetic signal. Intrusions 1 and 2 are inversely magnetized and are coincident with the zones of fast seismic velocities (approximately $7.5 \mathrm{~km} / \mathrm{s}$ ) in the lower continental crust that were mapped in the refraction experiment (Figure 2a). The inferred intrusive bodies are dense, highly magnetic, and characterized by fast $V_{P}$ values. Similar intrusive 
bodies were interpreted by Filina (2019) in the northwestern and central GOM and by Filina and Hartford (2018) in the southern GOM. The dense intrusive structures in the lower crust can explain the presence of a flat Moho because intrusions of mafic melts can compensate for crustal thinning and a shallow Moho as observed in other rifts (Nielsen and Thybo, 2009).

\section{Model 2}

Model 2 was built along the Spectrum seismic reflection profile DeepEast 1547 (Figure 2c) and extends from offshore Florida toward the Yucatan margin (see the location in Figure 1). Model 2 consists of 14 layers down to a depth of $40 \mathrm{~km}$ (Figure $3 \mathrm{~b}$ ). Subsurface rocks were assigned the same physical properties as used in model 1 and shown in Figure 3a. One autochthonous salt body that overlies the marginal rift deposits was included in the model based on the interpretation of the seismic reflection image (Figure 2c).

The OCB is located at $336 \mathrm{~km}$ along model 2, and it is expressed as a magnetic low similar to the magnetic low observed along the OCB in model 1 (Figure 3b). The continental crust for model 2 was also modeled with an upper and lower continental crust with the same physical properties as shown in model 1 (Figure 3a). Similar to model 1, we added two intrusive bodies to the lower continental crust of model 2 at distances along the length of the seismic line between 70-200 (intrusion 1) and 280-323 km (intrusion 2). These intrusions in the lower crust are required to fit the magnetic profile, and are similar to other high-density magmatic bodies that underlie other continental rifts worldwide as discussed by Nielsen and Thybo (2009).

Because no seismic refraction data are available for model 2, the presence of higher seismic velocities cannot be established. Both intrusions have negative magnetic polarity and are modeled with a magnetic susceptibility of $-8000 \mu \mathrm{cgs}$, which is the same value as the magnetic susceptibility used for model 1. Similarly, one SSDR province, the AR, and the marginal rift were interpreted from seismic data and were included in model 2 (Figure $3 \mathrm{~b}$ ). The AR to the north occurs between the model distances of $40-103 \mathrm{~km}$, and the SSDR to the south $(216-273 \mathrm{~km})$ occurs adjacent to the marginal rift basin. 


\section{Tectonic structures from spatial analysis}

We determined the locations of the OCB, the marginal rift basin, and both northern and southern SDR provinces from the 2D models and correlated them with the lineaments in filtered potential fields that could be traced outside of the area of seismic reflection coverage (Figure 4). We used the tilt derivative transformation of the residual Bouguer gravity map (Figure 4a) and the first derivative filter of the residual RTP magnetic field (Figure $4 \mathrm{~d}$ ) to map the lateral extents of the OCB, the marginal rift, and both northern and southern SDR provinces. In general, the magnetic lineaments appear to be less pronounced than the gravity lineaments and likely reflect the different resolutions of these two data sets. Because the anomalies are better highlighted in the filtered gravity field than from magnetic data, the spatial analysis was primarily constrained using the filtered gravity map and then validated with the filtered magnetic field.

The locations of the OCB from the two models, i.e., approximately $301 \mathrm{~km}$ along model 1 (GUMBO3) and approximately $336 \mathrm{~km}$ along model 2, are shown on the filtered potential fields as the black ticks (Figure $4 \mathrm{~b}$ and $4 \mathrm{~d}$ ). These OCB locations correspond to the same gradient in the filtered gravity, which marks the edge of a pronounced basement high. On magnetic data, the OCB locations are marked by a linear magnetic low. These correlations were used to trace the OCB for the entire study area as shown in Figure 4. The SSDR province and NSDR/AR correspond to gravity and magnetic highs, whereas the marginal rift basin is expressed by a gravity and magnetic low.

Our analysis suggests that the width of the marginal rift basin decreases from 48 to $28 \mathrm{~km}$ on models 1 and 2, respectively. The thickness of the sedimentary fill in the marginal rift basin is approximately $3 \mathrm{~km}$ in both models. According to our spatial analysis, the marginal rift wedges out to the east of model 2, and it is bounded by the southward-dipping SSDR province in the north and the OCB in the south (Figure $4 \mathrm{~b}$ and $4 \mathrm{~d})$. The AR has an average width of $65 \mathrm{~km}$ and an average thickness of $10 \mathrm{~km}$, whereas the southward-dipping SSDR province is approximately $48 \mathrm{~km}$ wide and approximately $7 \mathrm{~km}$ thick (Figure 4).

\section{Discussion}

As a result of our integrated modeling, we have derived physical properties (density and magnetic susceptibility) for both regional seismic profiles 


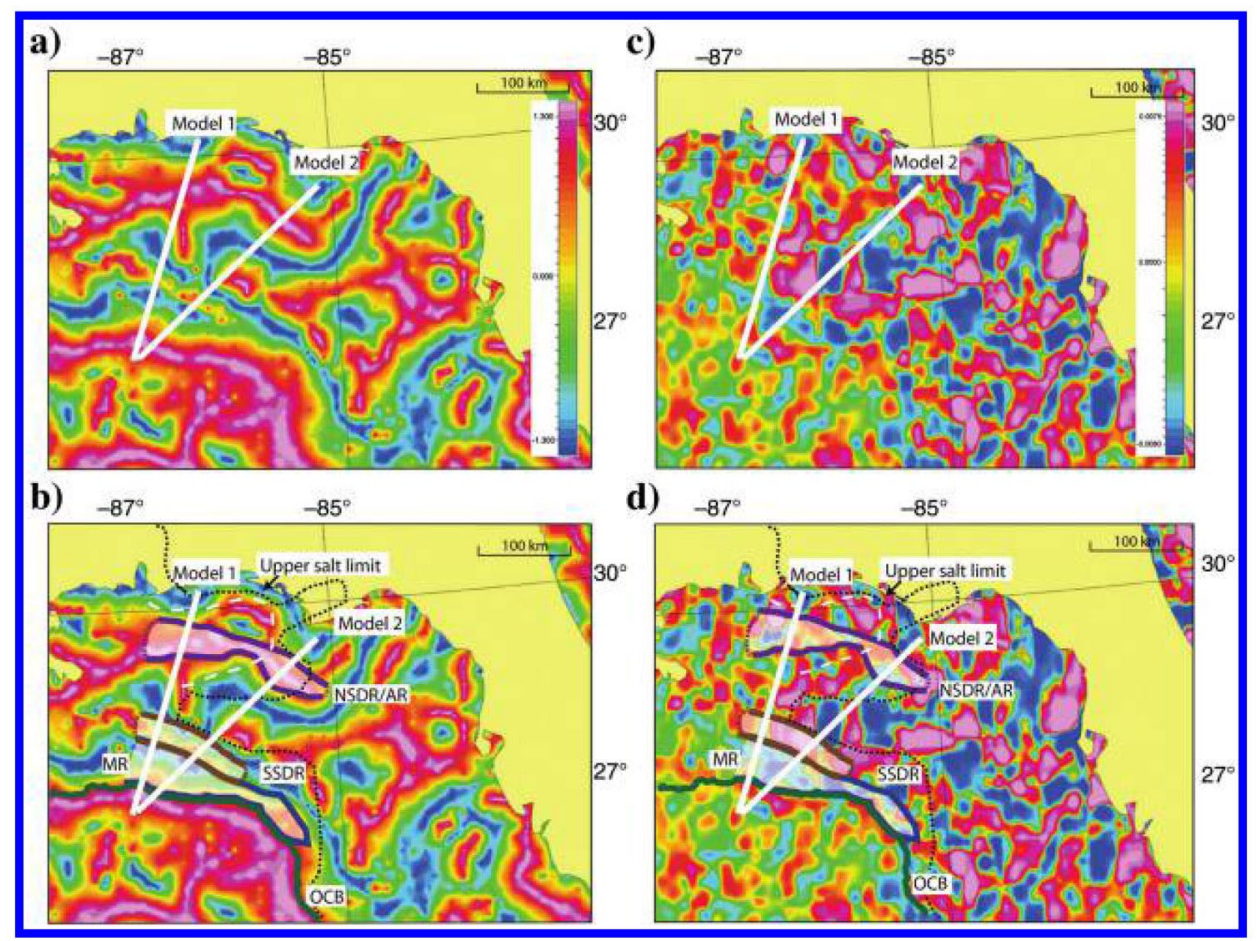

Figure 4. Continental margin rift structure, northern and southern SDR provinces, and the OCB as interpreted from spatial analysis of potential fields and constrained from models 1 and 2. The filtering process is described in the text. (a) Tilt derivative of the residual Bouguer gravity map. (b) Tilt derivative of the residual Bouguer gravity map showing locations of the SSDR and NSDR/AR provinces, OCB, and marginal rift basin. (c) First vertical derivative of the RTP magnetic map. (d) First vertical derivative of the RTP magnetic map with interpretations from this study. The purple line marks the boundaries of the NSDR/AR province, whereas the brown line shows the SSDR province. The dashed lines on the two sides of the mapped structures indicate the uncertainty of the spatial interpretation. The marginal rift basin is outlined by a dark blue line, and the OCB is shown in green. The black dotted line shows the updip limit of the Louann salt from Rowan (2014) and Steier and Mann (2019). The dashed white line shows the eastern boundary of the AB from Dobson and Buffler (1997).

(Figure $3 \mathrm{a}$ and $3 \mathrm{~b}$ ). These physical properties are either constrained by well data (sedimentary layers and upper continental crust) or with published values from previous gravity and magnetic models for the GOM (Filina et al., 2015). The modeled intrusive bodies share the same value of magnetic susceptibility, and their magnetic polarity pattern is also consistent between both modeled profiles. The locations of intrusions 1 and 2 on model 1 correspond to the fast $\mathrm{V}_{\mathrm{P}}$ zone in the refraction experiment results described by Eddy et al. (2014) (Figure 2a) and Van Avendonk et al. (2015). 
The derived OCB locations for models 1 (Figure 3a) and 2 (Figure 3b) are constrained from both potential field data sets, although the magnetic field appears to be more precise than the gravity field for defining the OCB location. The $3 \mathrm{~km}$ thick marginal rift section interpreted in model 1 from seismic reflection data (Figure 2b) is also consistent with the observed magnetic profile. The marginal rift section thins to the southwest in both models and likely reflects the extreme thinning of the underlying continental crust in the direction of the adjacent oceanic crust (Figure 3a and $3 b$ ). The NSDR and SSDR provinces require denser and more magnetic rocks with respect to the upper continental crust to interpret the observed gravity and magnetic signals (Figure $4 \mathrm{a}$ and $4 \mathrm{~b}$ ). The NSDR province appears to be wider $(65 \mathrm{~km})$ and longer $(285 \mathrm{~km})$ than the SSDR (48 $\mathrm{km}$ wide and $235 \mathrm{~km}$ long). The SSDR province is approximately $22 \mathrm{~km}$ wider and $63 \mathrm{~km}$ longer than the same province as determined by Eddy et al. (2014) (Figure 1, $26 \mathrm{~km}$ wide and $172 \mathrm{~km}$ long). The northwestern edge of the SSDR province from Eddy et al. (2014) differs from the edge that we propose in this study from the potential fields data (Figure 1). Using the DeepEast seismic reflection data set, we extend the SSDR to the northwest beyond the limits of the SDR mapped by Eddy et al. (2014).

We support previous workers that the southward-dipping, layered units within the northern AR and adjacent to the marginal rift in the south are SDRs of magmatic origin. Previous SDR interpretations include Imbert (2005), Imbert and Philippe (2005), Eddy et al. (2014), van Avendonk et al. (2015), Pascoe et al. (2016), and Curry et al. (2018).

A magmatic origin for the two areas of SDRs is consistent with the observed and modeled higher densities and magnetic susceptibilities in both of these areas (Figure 3a and $3 b$ ) and the uniform seaward (southwestward) dip of the reflectors in both areas. It is clear that the northern area of NSDRs was erupted within the AR (Figure 4) while the southern area of the SSDRs erupted adjacent to the marginal rift approximately at $162 \mathrm{Ma}$ (Eddy et al., 2014). The top of the NSDR unit is truncated by the postrift sag basin that overlies the AR (Figure $5 \mathrm{~d}$ and $5 \mathrm{f}$ ).

The dip of these NSDR volcanic rocks within the AR were possibly erupted along the bounding normal faults along the northern edge of the rift (Figure $5 \mathrm{~d}$ and $5 \mathrm{f}$ ). A Precambrian analog for voluminous volcanic rocks infilling the AR is the Midcontinent rift beneath Lake Superior where $8 \mathrm{~km}$ of volcanics and interbedded sedimentary rocks (velocity of $0.5-6.5 \mathrm{~km} / \mathrm{s}$ ) erupted from bounding normal faults and infilled 


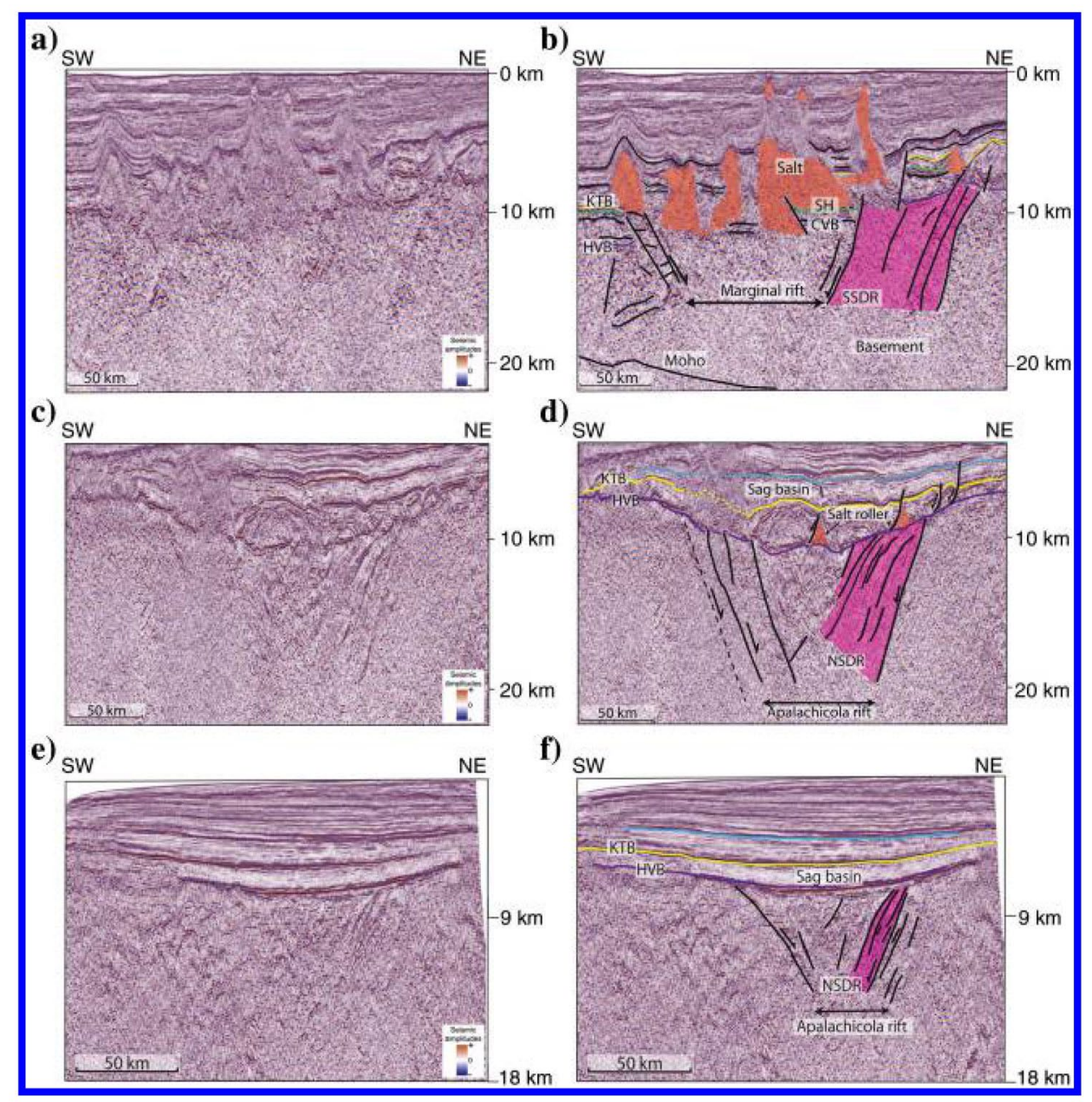

Figure 5. (a) Uninterpreted depth-migrated seismic reflection data of the marginal rift on line 1. (b) Seismic interpretation for the juxtaposition of the marginal rift and SSDR. The age control is from well LL399 (Figure 1). KTB, Navarro-Taylor Formations (66$123 \mathrm{Ma}$ ); SH, Sligo-Hosston Formations (123-138 Ma); CVB, Cotton Valley-Bossier Formations (138-142 Ma); and HVB, Top Haynesville-Buckner Formations (152 Ma) are the horizons interpreted in this study based on ties shown in Snedden et al. (2013) and Lin et al. (2019). (c) Uninterpreted depth-migrated seismic reflection data of the $\mathrm{AR}$ and its overlying sag basin. (d) Seismic interpretation of the infill and bounding normal faults of the $10 \mathrm{~km}$ thick AR. The red polygon shows the $10 \mathrm{~km}$ thick, volcanic flows along the northeastern edge of the rift. (e) Uninterpreted depth-migrated seismic reflection section of the Spectrum DeepEast 1547. (f) Interpretation of the $8 \mathrm{~km}$ thick, eastern AR with a $7 \mathrm{~km}$ thick NSDR shown in the red. Previous workers have noted that the AR thins and eventually disappears in an eastward direction. 
the central axis of the rift (Behrend et al., 1988; Shay and Tréhu, 1993). A well-developed, symmetrical sag basin up to $1-3 \mathrm{~km}$ in thickness overlies the AR. The vertical relief of the sag basin promoted the downslope motion of the salt rollers (Figure $5 \mathrm{~d}$ ) during the postrift period.

In contrast to the NSDR volcanics confined to the AR, the SSDR province appears to have formed outside of the adjacent marginal rift (Figure 5b) as observed on coeval Mesozoic Atlantic rifted margins (E1dholm et al., 1995; Tian and Buck, 2019). The SSDR in the northern GOM occupies structurally higher level relative to the adjacent marginal rift and therefore appears to have formed prior to the phase 2 marginal rift adjacent to oceanic crust beneath the central GOM (Figure 5b). The west-to-northwest orientation of the marginal rift and parallelism with the OCB is consistent with its formation during the Late Jurassic Phase 2 rifting during rotation of the Yucatan block and immediately preceded the formation of Late Jurassic oceanic crust (Lin et al., 2019; Steier and Mann, 2019) (Figure 1). The parallel, west-northwest orientation and shape of the AR and its overlying sag basin indicate that it likely propagated in an eastward direction (Figure $5 \mathrm{~d}$ and 5f). Salt thickens in the sag basin overlying the wider western end of the rift (Figure 5d) and thins and disappears in the thinner sag basin overlying the narrower eastern end of the basin (Figure 5f). The unusual, west-northwest trend of the AR in comparison with more northeasterly Phase 1 rifts may indicate that the AR may have formed as a transitional rift between the northeast-striking Phase 1 rifts and the marginal rifts that formed adjacent to the initial, Late Jurassic oceanic crust (Lin et al., 2019).

\section{Conclusion}

We developed two integrated geophysical models along 300-km-long seismic reflection profiles crossing the rifted, continental margin of the northeastern GOM based on combined analysis of seismic, gravity, magnetics, and well data. Our seismic data and gravity and magnetic modeling constrain a $3 \mathrm{~km}$ thick sedimentary fill in the Late Jurassic Phase 2 marginal rift adjacent to oceanic crust that includes reactivated and highly deformed salt deposits that are thicker in the marginal rift than in adjacent areas (Figures 2b, 2c, 3a, and 3b). Gravity and magnetic modeling show that the marginal rift basin is $42 \mathrm{~km}$ wide along seismic line 
1, narrows to a width of $28 \mathrm{~km}$ along seismic line 2 , and disappears to the east. The marginal rift that we describe is similar in dimensions and thickness to those described along the Yucatan-Florida conjugate margin (Steier and Mann, 2019) and the northwestern GOM-Campeche conjugate margin (Hudec and Norton, 2019) (Figure 1).

The marginal rift in our study area is adjacent to the $48 \mathrm{~km}$ wide SSDR magmatic province of southward-dipping reflectors along its northern flank and by the down-to-the-north "step-up fault" bounding the OCB along its southern flank (Figure $4 \mathrm{~b}$ and $4 \mathrm{~d}$ ). The SSDR magmatic province is estimated to be $48 \mathrm{~km}$ wide and $235 \mathrm{~km}$ long.

We interpret another $65 \mathrm{~km}$ wide and $285 \mathrm{~km}$ long province of dense and highly magnetic rocks similar to SSDR that is entirely contained within the Apalachicola rift as well defined on both seismic reflection lines (Figure $2 \mathrm{~b}$ and $2 \mathrm{c}$ ). Based on our potential field modeling, both areas of SDRs exhibit high density and high magnetic susceptibility that is consistent with their proposed magmatic origin (Figure $5 \mathrm{~d}$ and $5 \mathrm{f}$ ).

We propose that the AR may have propagated eastward because it becomes narrower and exhibits a smaller overlying sag basin in its eastern area (Figure 5f). The anomalous east-to-southeast trend of the Apalachicola rift contrasts with other Triassic-Early Jurassic rifts in the southeastern US and may indicate that the AR may have formed as a transitional rift between the northeast- trending phase 1 rifts and the more east-west phase 2 marginal rift adjacent to oceanic crust (Figure 1). The integration of multiple geophysical data sets resulted in much better constrained crustal structures than those derived from 2D seismic alone.

Acknowledgments We thank M. Saunders and Spectrum Geo for providing the seismic reflection data used in this study and Geosoft for providing the educational license of Oasis Montaj software that was used in gravity and magnetic modeling. We thank R. Keller, E. Beutel, an anonymous reviewer, and associate editor D. Herron for their constructive comments that improved this paper. We thank the industry sponsors of the Conjugate Basins, Tectonics, and Hydrocarbons Consortium of the University of Houston for their continuing support.

Data and materials Data associated with this research are confidential and cannot be released. 


\section{References}

Bankey, V., A. Cuevas, D. Daniels, C. A. Finn, I. Hernandez, P. Hill, R. Kucks, W. Miles, M. Pilkington, C. Roberts, W. Roest, V. Rystrom, S. Shearer, S. Snyder, R. Sweeney, J. Velez, J. D. Phillips, and D. Ravat, 2002, Digital data grids for the magnetic anomaly map of North America: Open-File Report 02-414.

Behrend, J. C., A. G. Green, W. F. Cannon, D. R. Hutchinson, M. W. Lee, B. Milkereit, W. F. Agena, and C. Spencer, 1988, Crustal structure of the Midcontinent rift system: Results from GLIMPCE deep seismic reflection profiles: Geology, 16, 81-85, https://doi.org/10.1130/0091-7613(1988)016<0081:csotmr> 2.3.co;2

Bird, D. E., K. Burke, S. A. Hall, and J. F. Casey, 2005, Gulf of Mexico tectonic history: Hotspot tracks, crustal boundaries, and early salt distribution: AAPG Bulletin, 89, 311-328, https://doi.org/10.1306/10280404026

Buffler, R. T., and D. S. Sawyer, 1985, Distribution of crust and early history, Gulf of Mexico Basin: Gulf Coast Association of Geological Societies Transactions, 35, 333-344.

Buffler, R. T., W. Schlager, J. L. Bowdler, P. H. Cotillon, R. B. Halley, H. Kinoshita, L. B. Magoon, III, C. L. McNulty, J. W. Patton, K. A. Pisciotto, I. Premoli Silva, O. Avello Suarez, M. M. Testarmata, R. V. Tyson, and D. K. Watkins, 1984, Site 538: Deep Sea Drilling Project, 77, 279-336, https://doi.org/10.2973/dsdp. proc. 77.104 .1984

Carlson, R. L., and C. N. Herrick, 1990, Densities and porosities in the oceanic crust and their variations with depth and age: Journal of Geophysical Research: Solid Earth, 95, 9153-9170, https://doi.org/10.1029/jb095ib06p09153

Christeson, G. L., H. J. A. van Avendonk, I. O. Norton, J. W. Snedden, D. R. Eddy, G. D. Karner, and C. A. Johnson, 2014, Deep crustal structure in the eastern Gulf of Mexico: Journal of Geophysical Research: Solid Earth, 119, 6782-6801, https://doi.org/10.1002/2014jb011045

Curry, M. A. E., F. J. Peel, M. R. Hudec, and I. O. Norton, 2018, Extensional models for the development of passive- margin salt basins, with application to the Gulf of Mexico: Basin Research, 30, 1180-1199, https://doi.org/10.1111/ bre.12299

Dobson, L. M., and R. T. Buffler, 1997, Seismic stratigraphy and geologic history of Jurassic rocks, northeastern Gulf of Mexico: AAPG Bulletin, 81, 100-120, https://doi.org/10.1306/522b42a3-1727-11d7-8645000102c1865d

Duncan, M. H., 2013, The northeastern Gulf of Mexico: Volcanic or passive margin? Seismic implications of the Gulf of Mexico basin opening project: M.S. thesis, University of Texas at Austin.

Eddy, D. R., H. J. A. Van Avendonk, G. L. Christeson, and I. O. Norton, 2018, Structure and origin of the rifted margin of the northern Gulf of Mexico: Geosphere, 14, 1804-1817, https://doi.org/10.1130/ges01662.1 
Eddy, D. R., H. J. A. van Avendonk, G. L. Christeson, I. O. Norton, G. D. Karner, C. A. Johnson, and J. W. Snedden, 2014, Deep crustal structure of the northeastern Gulf of Mexico: Implications for rift evolution and seafloor spreading: Journal of Geophysical Research: Solid Earth, 119, 6802-6822, https://doi. org/10.1002/2014jb011311

Eldholm, O., J. Skogseid, S. Planke, and T. P. Gladczenko, 1995, Volcanic margin concepts, in E. Banda, M. Torné, and M. Talwani, eds., Rifted ocean-continent boundaries: Springer, Dordrecht, 1-16, https://doi. org/10.1007/978-94-011-0043-4 1

Escalona, A., and W. Yang, 2013, Subsidence controls on foreland basin development of northwestern offshore Cuba, southeastern Gulf of Mexico: AAPG Bulletin, 97, 1-25, https://doi.org/10.1306/06111212002

Filina, I., 2018, Integration with non-seismic methods: An example from the Northern Gulf of Mexico: AAPG Datapages/ Search and Discovery Article 2856122 .

Filina, I., N. Delebo, G. Mohapatra, C. Coble, G. Harris, J. Layman, M. Strickler, and J.-P. Blangy, 2015, Integration of seismic and gravity data - A case study from the western Gulf of Mexico: Interpretation, 3, no. 4, SAC99-SAC106, https://doi.org/10.1190/int-2015-0050.1

Filina, I., 2019, Crustal architecture of the northwestern and central Gulf of Mexico from integrated geophysical analysis: Interpretation, 1-61, https://doi. org/10.1190/int-2018-0258.1

Filina, I., and L. Hartford, 2018, Subsurface structures along the western Yucatan from integrative geophysical analysis: AGU Fall Meeting.

Filina, I., and L. Hartford, 2019, Integrated analysis of seismic data and potential fields in Southeastern Gulf of Mexico with implications to pre-salt sediments and crustal architecture: AAPG Annual Convention, Program with Abstracts. Gulf Oil Corporation, 1975, Scanned well report OCSG02468, https://www.boem.gov , accessed 16 April 2018.

Hilterman, F., 1998, Rock property framework for comprehending deep-water seismic response: Presented at the 14th Annual SEG Gulf Coast Technical Meeting.

Hudec, M. R., and I. O. Norton, 2019, Upper Jurassic structure and evolution of the Yucatán and Campeche subbasins, southern Gulf of Mexico: AAPG Bulletin, 103, 1133-1151, https://doi.org/10.1306/11151817405

Hudec, M. R., I. O. Norton, M. P. A. Jackson, and F. J. Peel, 2013, Jurassic evolution of the Gulf of Mexico salt basin: AAPG Bulletin, 97, 1683-1710, https://doi. org/10.1306/04011312073

Huffman, A. C. J., S. A. Kinney, L. Biewick, H. R. Mitchell, and G. L. Gunther, 2004, Gulf Coast Geology (GCG) Online-Miocene of Southern Louisiana, Version 1: USGS Data Series 90-A, https://doi.org/10.3133/ds90A27

Imbert, P., 2005, The Mesozoic opening of the Gulf of Mexico-Part 1: Evidence for oceanic accretion during and after salt deposition: 25th Annual Bob F. Perkins Research Conference: Petroleum Systems of Divergent Continental Margin Basins, 1119-1150. 
Imbert, P., and Y. Philippe, 2005, The Mesozoic opening of the Gulf of Mexico Part 2: Integrating seismic and magnetic data into a general opening model: 25th Annual Bob F. Perkins Research Conference: Petroleum Systems of Divergent Continental Margin Basins, 1151-1189.

Lin, P., 2018, Crustal structure and tectonostratigraphic evolution of the eastern Gulf of Mexico Basin: Ph.D. dissertation, University of Houston.

Lin, P., D. E. Bird, and P. Mann, 2019, Crustal structure of an extinct, late Jurassicto-earliest Cretaceous spreading center and its adjacent oceanic crust in the eastern Gulf of Mexico: Marine Geophysical Research, 1-24, https://doi. org/10.1007/s11001-019-09379-5

MacRae, G., and J. S. Watkins, 1995, Early Mesozoic rift stage half graben formation beneath the DeSoto Canyon salt basin, northeastern Gulf of Mexico: Journal of Geophysical Research: Solid Earth, 100, 17795-17812, https://doi. org/10.1029/95jb00763

Marton, G., and R. T. Buffler, 1994, Jurassic reconstruction of the Gulf of Mexico Basin: International Geology Review, 36, 545-586, https://doi. org/10.1080/00206819409465475

Marton, G. L., and R. T. Buffler, 1999, Jurassic-early cretaceous tectonopaleogeographic evolution of the southeastern Gulf of Mexico basin, in P. Mann, ed., Caribbean basins: Sedimentary basins of the world: Elsevier Science B. V., Amsterdam, 4, 63-91.

Meyer, B., R. Saltus, and A. Chulliat, 2017, EMAG2: Earth magnetic anomaly grid (2-arc-minute resolution) version 3: National Center for Environmental Information, NOAA, https://doi.org/10.7289/V5H70CVX

Nguyen, L. C., and P. Mann, 2016, Gravity and magnetic constraints on the Jurassic opening of the oceanic Gulf of Mexico and the location and tectonic history of the Western Main transform fault along the eastern continental margin of Mexico: Interpretation, 4, no. 1, SC23-SC33, https://doi.org/10.1190/int-2015-0110.1

Nielsen, C., and H. Thybo, 2009, No Moho uplift below the Baikal rift zone: Evidence from a seismic refraction profile across southern Lake Baikal: Journal of Geophysical Research: Solid Earth, 114, 1-22, https://doi. org/10.1029/2008jb005828

Pascoe, R., P. Nuttall, D. Dunbar, and D. Bird, 2016, Constraints on the timing of continental rifting and oceanic spreading for the Mesozoic Gulf of Mexico Basin, in C. M. Lowery, J. W. Snedden, and N. C. Rosen, eds., Mesozoic of the gulf rim and beyond: New progress in science and exploration of the Gulf of Mexico Basin, Gulf Coast Section SEPM Foundation, 81-122, https://doi.org/10.5724/ gcs.15.35.0081

Pindell, J., E. C. Miranda, A. Cerón, and L. Hernandez, 2016, Aeromagnetic map constrains Jurassic-Early cretaceous synrift, break up, and rotational seafloor spreading history in the Gulf of Mexico, in C. M. Lowery, J. W. Snedden, and N. C. Rosen, eds., Mesozoic of the Gulf Rim and beyond: New progress in science and exploration of the Gulf of Mexico Basin: SEPM Society for Sedimentary Geology 35, 123-153. 
Pindell, J. L., and L. Kennan, 2009, Tectonic evolution of the Gulf of Mexico, Caribbean and northern South America in the mantle reference frame: An update, in K. H. James, M. A. Lorente, and J. L. Pindell, eds., The origin and evolution of the Caribbean plate: Geological Society of London Special Publications 328, $1-55$.

Planke, S., P. A. Symonds, E. Alvestad, and J. Skogseid, 2000, Seismic volcano stratigraphy of large-volume basaltic extrusive complexes on rifted margins: Journal of Geophysical Research: Solid Earth, 105, 19335- 19351, https://doi. org/10.1029/1999jb900005

Rowan, M. G., 2014, Passive-margin salt basins: Hyperextension, evaporite deposition, and salt tectonics: Basin Research, 26, 154-182, https://doi. org/10.1111/bre.12043

Sandwell, D. T., R. D. Muller, W. H. F. Smith, E. Garcia, and R. Francis, 2014, New global marine gravity model from CryoSat-2 and Jason-1 reveals buried tectonic structure: Science, 346, 65-67, https://doi.org/10.1126/science.1258213

Schnetzler, C. C., 1985, An estimation of continental crust magnetization and susceptibility from Magsat data for the conterminous United States: Journal of Geophysical Research: Solid Earth, 90, 2617-2620, https://doi.org/10.1029/ jb090ib03p02617

Shay, J., and A. Tréhu, 1993, Crustal structure of the central graben of the Midcontinent Rift beneath Lake Superior: Tectonophysics, 225, 301-335, https:// doi.org/10.1016/0040-1951(93)90303-2

Snedden, J., D. Eddy, G. Christeson, H. Van Avendonk, H. Olson, P. GaneyCurry, and I. Norton, 2013, A new temporal model for Eastern Gulf of Mexico Mesozoic deposition: Gulf Coast Association of Geological Societies Transactions, 63, 609-612.

Snedden, J. W., I. O. Norton, G. L. Christeson, and J. C. Sanford, 2014, Interaction of deepwater deposition and a Mid-Ocean spreading center, Eastern Gulf of Mexico Basin, USA: Gulf Coast Association of Geological Societies Transactions, 64, 371-383.

Steier, A., and P. Mann, 2019, Late Mesozoic gravity sliding and Oxfordian hydrocarbon reservoir potential of the northern Yucatan margin: Marine and Petroleum Geology, 103, 681-701, https://doi.org/10.1016/j. marpetgeo.2019.03.001

Tian, X., and W. R. Buck, 2019, Lithospheric thickness of volcanic rifting margins: Constraints from seaward dipping reflectors: Journal of Geophysical Research: Solid Earth, 124, 3254-3270, https://doi.org/10.1029/2018JB016733

Van Avendonk, H. J. A., G. L. Christeson, I. O. Norton, and D. R. Eddy, 2015, Continental rifting and sediment infill in the northwestern Gulf of Mexico: Geology, 43, 631- 634, https://doi.org/10.1130/g36798.1

Warwick, P. D., 2017, Geologic assessment of undiscovered conventional oil and gas resources in the Lower Paleogene Midway and Wilcox Groups, and the Carrizo Sand of the Claiborne Group, of the Northern Gulf coast region: USGS OpenFile Report 2017-1111, https://doi.org/10.3133/ofr20171111 


\section{The Authors}

Mei Liu received a B.S. (2016) and an M.S. (2018) in geology from the University of Nebraska-Lincoln. She is currently pursuing a Ph.D. in geology, and she is a graduate research assistant with the Conjugate Basins, Tectonics, and Hydrocarbons (CBTH) industry consortium at the Department of Earth and Atmospheric Sciences of the University of Houston. Her research interests include application of integrating seismic and potential field methods to understand the tectonic evolution of the GOM.

Irina Filina received a Ph.D. (2007) in geophysics from the University of Texas at Austin. She worked in the petroleum industry for eight years before joining the University of Nebraska at Lincoln in 2016. She is currently leading the UNL Geophysics Research Group. Her research interests include understanding the tectonic history of the GOM and midcontinent rift in Nebraska.

Paul Mann received a B.A. in geology from Oberlin College and a Ph.D. from the State University of New York at Albany. He worked for many years as a research scientist at the Institute for Geophysics at the University of Texas at Austin. In 2011, he became the Robert E. Sheriff endowed professor of geology in the Department of Earth and Atmospheric Sciences at the University of Houston. He has numerous publications and edited volumes on the tectonics, geology, geophysics, and petroleum geology of the circum-Caribbean regions and southwest Pacific Ocean. He is a fellow of the Geological Society of America, an associate editor of the journal Marine Geophysical Research, and the director of the CBTH industry consortium at the University of Houston. 